Marquette University

e-Publications@Marquette

4-1-1998

Aquinas, the Plotiniana Arabica, and the Metaphysics of Being and Actuality

Richard C. Taylor

Marquette University, richard.taylor@marquette.edu

Published version. Journal of the History of Ideas, Vol.59, No. 2 (April, 1998): 217-239. Permalink. (C) 1998 University of Pennsylvania Press. Used with permission. 


\title{
Aquinas, the Plotiniana Arabica, and the Metaphysics of Being and Actuality
}

\author{
Richard C. Taylor
}

Historians of Western philosophy have long thought that the Liber de causis played an important role in the formation of metaphysical thinking in the Latin West following its translation in the mid-twelfth century. ${ }^{1}$ This was clearly based on the incorporation of this work into required philosophical studies at the University of Paris and elsewhere as well as on the frequent citation of or even commentary on the doctrines of the Liber de causis. The text generated at least 27 different Latin commentaries and is extant today in Latin in nearly 240 manuscripts. ${ }^{2}$ Doctrinally, the text played a very significant role in the thought of philosophers and theologians of the thirteenth century, particularly with its notion of being as alone caused in things by God, who is described as esse tantum and ens primum. ${ }^{3}$ Both notions were used by Thomas Aquinas as early as the time when he wrote his De ente et essentia, in which he asserted that God's essence and quiddity are his being and that the notion of God as pure being or esse tantum is not to be understood as formed by abstraction upon the

Thanks to the American Philosophical Society and Marquette University for financial support for research and also to Rev. Joseph Owens, John Rist, Rev. H. D. Saffrey, Rev. Lawrence Dewan, O.P., Cristina D'Ancona Costa, John Murdoch, Kevin Staley, and Arthur Hyman as well as my Marquette University colleagues Owen Goldin, David Twetten, John Jones, Michael Wreen, Rev. Alexander Golitzin, and James South for helpful suggestions.

${ }^{1}$ See, for example, H. D. Saffrey, "L'êtat actuel des recherches sur le Liber de causis comme sources de la métaphysique au moyen âge," in Die Metaphysik im Mittelalter (Miscellanea Mediaevalia, 2) (Berlin, 1963), 267-81.

${ }^{2}$ See Richard C. Taylor, "The Liber de causis: A Preliminary List of Extant MSS," Bulletin de philosophie médiévale, 25 (1983), 63-84.

${ }^{3}$ Liber de causis, proposition VIII 90.02 and proposition XVII 143.38. All citations of the Latin text are to the edition of Adriaan Pattin in "Le Liber de causis," Tijdschrift voor Filosofie, 28 (1966), 90-203, incorporating the changes suggested in Richard C. Taylor, "Remarks on the Latin Text and the Translator of the Kalâm fî mahd al-khair/Liber de causis," Bulletin de philosophie médiévale, 31 (1989), 75-102. 
consideration of ens commune. ${ }^{4}$ But exactly how such doctrines are to be understood and how they fit into the historical development of philosophy from ancient times through the medieval period has not been clear. Such was the case in part because of the lack of a critical text and in part because of the lack of studies of the Liber de causis in relation to sources. ${ }^{5}$ Without such tools the sense of this work's doctrines could not be grasped in their proper historical context, and the role of the Liber de causis in the history of philosophy could only be a matter of tentative speculation.

Scholars pursuing a comprehensive understanding of the history of philosophy seek to incorporate into their work all that is available from historical, textual, and philosophical studies. A good example of this is perhaps the approach of Etienne Gilson to the question of the Thomistic doctrine of essence and existence in relation to developments in the history of philosophy in ancient and medieval times. In both L'Etre et l'essence ${ }^{6}$ and the earlier Being and Some Philosophers Gilson sharply contrasts the philosophy of Plotinus with that of Thomas Aquinas on the nature of the first principle of all, stressing that the metaphysics of Plotinus is a metaphysics of the One or Unity, a kind of Henology, while holding that for Thomas Aquinas metaphysics deals with being or esse and that the first principle is Esse itself. ${ }^{7}$ Such an understanding of Aquinas and Plotinus would appear to be well founded.

Yet while Aquinas incorporates much of the philosophical reflection on the nature of being found in the work of Aristotle and Parmenides, he also transcends their reflections in his presentation of his understanding of the divine nature. For Parmenides being is to be regarded as indivisible, continuous, ${ }^{8}$ motionless, ungenerated, imperishable, without beginning or end, and (perhaps most importantly for the history of metaphysics) finite; "for strong Necessity holds it firm within the bonds of the limit that keeps it back on every side, because it is not lawful that what is should be unlimited; for it is not in needif it were, it would need all."" This "strong Necessity" is not the result of some-

${ }^{4}$ De ente et essentia, ed. Leonine (Rome 1976), 378.1-29.

${ }^{5}$ The text is edited with English translation and accompanying studies and notes in Richard C. Taylor, The Liber de causis (Kalâm fì maḥ al-khair: A Study of Medieval Neoplatonism (Ph.D. diss., University of Toronto, 1981). Earlier published editions are the following: Otto Bardenhewer, Die pseudo-aristotelische Schrift ueber das reine Gute bekannt unter dem Namen Liber de causis (Freiburg, 1882); Abdurrahman Badawi, Al-Aflâtûnîyah al-muḥdathah ${ }^{c}$ inda alcarab (Cairo, 1955; Kuwait, 1977).

${ }^{6}$ L'Etre et l'essence (Paris, $19722^{2}$ ). See 44-48; 327-30.

${ }^{7}$ Etienne Gilson, Being and Some Philosophers (Toronto 1949; 19612), 20-29 and 178ff.

${ }^{8}$ Parmenides, Fr. 8, 1.26; G. S. Kirk and J. E. Raven (eds.), The Presocratic Philosophers (Cambridge, 1969), no. 348, 275.

${ }_{9}^{9}$ Parmenides, Fr. 8, 11.30-33 (Kirk and Raven, no. 350), 276. For the purposes of this article, what is important is that the notion of being is accompanied by the notion of determination. The question of whether Parmenides considered What Is to have spatial limitaions is not crucial for my argument here. On that topic, see G. E. L. Owen, "Eleatic Questions," repr. in Logic, Science, and Dialectic: Collected Papers in Greek Philosophy / G. E. L. Owen, ed. Martha Nussbaum (Ithaca, N.Y., 1986), 3-26, esp. 22. 
thing outside being, for outside it nothing is; rather, Being is self-limited and everywhere equal within its own bounds because of its very nature. ${ }^{10}$ For Aristotle, too, being is finite, although in a different sense; and he follows Plato in maintaining the primacy of form in his understanding of being. Plato and Aristotle are both dependent on the notion of the concomitant nature of being and thought found in the Poem of Parmenides. ${ }^{11}$ For both Plato and Aristotle the relation of being and thought yielded a conception of being as form and intelligibility. Of course, for Plato forms existing separate from the material things of the world have priority in being. ${ }^{12}$

Aristotle, however, emphasizes the immanence of form as act and intelligibility of the individual substance or ovंia and views form as that which primarily deserves the name of ov $\sigma i a .{ }^{13} \mathrm{He}$ argues to the reality of a plurality of unmoved movers in book $\Lambda \alpha ́ \mu \beta \delta \alpha$ of his Metaphysics (the final causes which move others through the perfect finality immanent in them qua most actual instances of ovं ía), and here he is bound by his own thought to regard these as individual and as completely actual instances of being. ${ }^{14}$ When Aristotle says, quoting the Iliad, ${ }^{15}$ "The rule of many is not good; let there be one ruler," he is here designating a primum inter pares, not a transcendently more complete actual instance of ov́ria. ${ }^{16}$ Thus it seems not at all unfair or incorrect to state that Aristotle seems not to have given serious consideration to being outside of or beyond what Aquinas would call ens commune or esse commune. Consequently, from the perspective of Aquinas one might say that, confined within a philosophical and conceptual framework set down by Parmenides as mediated by a Platonic understanding of ovं ía as form, Aristotle never saw fit to affirm the reality of a transcendent efficient cause of being, a cause of esse commune outside esse commune, which cause is itself ipsum esse per se subsistens as we find in the thought of Aquinas. ${ }^{17}$

Plato strained at the reins or limits set by Parmenidean thought while clearly laying the foundations for the thought of Aristotle in his own Theory of Ideas

${ }^{10}$ Parmenides, Fr. 8, 1.49 (Kirk and Raven, no. 351), 276.

${ }^{11}$ Parmenides, Fr. 8, 1.34 (Kirk and Raven, no. 352), 277.

${ }^{12}$ See e.g., Republic 476D; 507B-C; 508 E ss.

${ }^{13}$ See Metaphysics VII 17 and IX 8.

${ }^{14}$ On this see Joseph Owens, The Doctrine of Being in the Aristotelian Metaphysics (Toronto, 1963), 438ff.

${ }^{15}$ Metaphysics 12.10, 1076a3, tr. W. D. Ross, revised by Jonathan Barnes, in The Complete Works of Aristotle. The Revised Oxford Translation, ed. Barnes (Princeton, 1984), II, 1700. Cf. Iliad II, 204.

${ }^{16}$ The only criterion for the ranking of these is the motion they cause. At any rate, as completely actual in itself, no one of the unmoved movers could be generated from another or influenced by another. This lacuna, if it is a lacuna, was filled by later thinkers (with the exception of the mature Averroes and some others) with theories of emanation and illumination.

${ }^{17}$ See De potentia dei, q.3, a.5. 
under the inspiration of Socrates and in reaction to Parmenides and the Sophists. ${ }^{18}$ This becomes clear in a number of works but perhaps most notably in the Republic and, if we are to adopt the approach of many a Neoplatonist, the Parmenides. ${ }^{19}$ In the Republic, after confronting Parmenidean notions in order to establish the realm of becoming, ${ }^{20}$ Plato goes on to consider the Ideas and the Idea of the Good. ${ }^{21} \mathrm{He}$ puts forth the doctrine that the idea of the Good is the cause of knowledge and truth; furthermore, since truth and the forms which are the objects of knowledge are found in the realm of being, he goes on to say, "you are to say that the objects of knowledge not only receive from the presence of the good their being

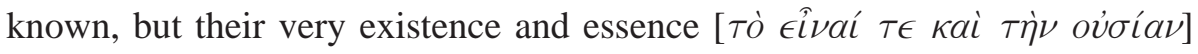
is derived to them from it, though the good itself is not essence [oúk ov́rías]

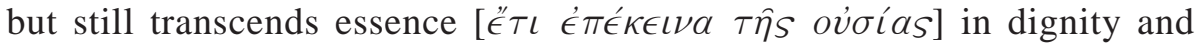
surpassing power." 22

A Neoplatonic approach to the second section of the Parmenides might yield a similar understanding. For it can be said that in the First Hypothesis concerning the One-which-is-not, Plato analyzes that which is above the Ideas and does not partake of being at all. ${ }^{23} \mathrm{He}$ goes so far as to conclude that "it has no being even so as to be one, for if it were one, it would be and would partake of being" 24 and that "it is neither named nor described nor thought of nor known, nor does any existing thing perceive it." 25 It is this One-which-is-not which might be understood to stand over the One-which-is, the object of the Second Hypothesis. Whether or not this approach to these texts is consonant with what he himself thought, it is clear that Plato pressed hard at the limits imposed even by his own thought, limits ultimately rooted in notions passed on by Parmenides.

Plotinus brings a new sort of understanding, placing the very cause of being and of everything which in any way exists outside the realm of being. Setting forth the doctrine that originated being must turn back to contemplate its cause for fulfillment, ${ }^{26}$ Plotinus held that $\nu$ ovs or the Intellectual Realm comes to be the source of forms for lower things. It is this being, taken together with what it causes posterior to itself, that would constitute what might

${ }^{18}$ This is evident in the Republic, the Parmenides, and the Sophist.

${ }^{19}$ On the Neoplatonic approach see Francis MacDonald Cornford, Plato and Parmenides (New York, n.d.), $131 \mathrm{ff}$.

${ }^{20}$ Republic 476E-477C.

${ }^{21}$ Republic 509A-B; 517B-C.

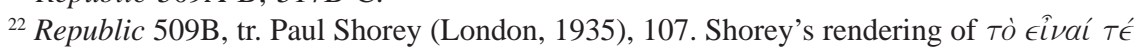

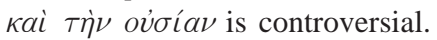

${ }^{23}$ Parmenides, 137C-142A.

${ }^{24}$ Parmenides, 141E, tr. H. N. Fowler (London, 1926), 252.

${ }^{25}$ Parmenides, 142A, Fowler, 252.

${ }^{26}$ See Plotinus, Enneads V. 2,1, in Plotini Opera II, ed. Paul Henry and Hans-Rudolf Schwyzer (Paris, 1959), including English translations of the Plotiniana Arabica by Geoffrey Lewis. See note 39. 
correspond to esse commune or ens commune in the thought of Aquinas. And, while for Plotinus the One is itself without definition, without limit, without form, without shape, above all being and predicates found in the realm of being, the first of the three initial hypostases, the Good, for Aquinas the First Principle of all is God who is ipsum esse per se subsistens. ${ }^{27}$ At first glance, then, there are apparent and basic parallels and similarities, but to Gilson these were only apparent.

There is a fundamental difference between the thought of Plotinus and that of Aquinas on the metaphysical understanding of the first principle, in spite of similarity. For in question 44, article 1 of the Summa theologiae, Aquinas says,

It must be said that everything, that in any way is, is from God. For whatever is found in anything by participation must be caused in it by that to which it belongs essentially, as iron becomes heated by fire. Now it has been shown above, when treating of the divine simplicity, that God is self-subsisting being itself [ipsum esse per se subsistens], and also that subsisting being can be only one; just as, if whiteness were self-subsisting, it would be one, since whiteness is multiplied by its recipients. Therefore all beings other than God are not their own being, but are beings by participation. Therefore it must be that all things which are diversified by the diverse participation of being, so as to be more or less perfect, are caused by the one First Being, Who possesses being most perfectly. ${ }^{28}$

While Plotinus refuses all names to the First Principle, the One, even the name of being, Aquinas, in this text and in many others, makes clear his understanding that God is ipsum esse per se subsistens in such a way that $\mathrm{He}$ is the very nature of Being as unparticipated efficient cause of being for all things that participate in being. ${ }^{29}$ This participation of being is brought about by Divine activity which is direct and without mediation in the giving of being. For Aquinas it is the esse as participated which gives actual existence to the nature which receives it in such a way that this limiting form quidditatively and formally determines what it receives, with these two together forming the

${ }^{27}$ Cf. Kevin Corrigan, "A Philosophical Precursor to the Theory of Essence and Existence in St. Thomas Aquinas," The Thomist, 48 (1984), 219-40; and "Essence and existence in the Enneads," in The Cambridge Companion to Plotinus, ed. Lloyd P. Gerson (New York, 1996), 105-29; see also Wayne Hankey, “Aquinas' First Principle: Being or Unity?” Dionysius, 4 (1980), 133-72.

${ }^{28}$ ST I 44, 1 resp. tr. from Basic Writings of Saint Thomas Aquinas, ed. Anton C. Pegis (New York, 1945), 427.

${ }^{29}$ See ST I 3, 8 ad 1; ST I 44, 1; De potentia dei, q.3, a.5; De spiritualibus creaturis, a.1 resp. Also $S T$ I 3, 8 ad 3. 
entitative composition that is the existing being or creature. ${ }^{30}$ In the teaching of Aquinas there is no confusion of Divine Being with that of creatures, just as there is no such confusion of the One with what it causes in the thought of Plotinus. Although Divine being is from God alone, since esse for Aquinas is given by efficient causality, it is not the formal being of its creatures. ${ }^{31}$ Consequently, it must be admitted that the doctrine of Aquinas does coincide with that of Plotinus in that the First is separate from its product and in that this First is infinite and above limit, definition, and form. ${ }^{32}$ Nevertheless, on the basis of the understandings available to him, Gilson seems to have had every right to remark that still for Plotinus

it becomes perfectly clear that being no longer is the first principle, either in metaphysics or in reality. To Plotinus, being is only the second principle, above which there is to be found a higher one, so perfect in itself that it is not. More than that, it is precisely because the first principle is not being that it can be the cause of being. ${ }^{33}$

Still, in light of similarities, can we rightly say that the ideas of Aquinas and Plotinus are radically at variance with one another? Is the difference between these two thinkers on the understanding of the first principle real or apparent? Could it not be that similar fundamental intuitions occurred separately to these two thinkers and that each expressed his thought within the philosophical tradition of the historical moment? Or could it be that the thought of Plotinus underwent modifications by one or more intermediaries and finally reached Aquinas, who examined the teaching critically and transformed it into his own?

We shall see that the Liber de causis and its proper understanding are central to any attempt to settle the issue of the historical relationship of the doctrines of Aquinas and Plotinus. Yet to understand this text one must consider also its origins in the thought of Proclus and the Plotiniana Arabica. ${ }^{34}$ This is so even though we do know that the texts which go to make up the materials

\footnotetext{
${ }^{30}$ The term "entitative composition" more accurately describes this than the traditional terminology derived from the word res; see Joseph Owens, An Elementary Christian Metaphysics (Milwaukee, 1963), 99-110.

${ }^{31}$ In I Sent. d.8, q.1, a.2, sol et ad 1 (Mandonnet I, 198).

${ }^{32}$ ST I 7, 1 resp. et ad 3.

${ }^{33}$ Etienne Gilson, Being and Some Philosophers (Toronto, 1952), 22.

${ }^{34}$ On the relationship of the Liber de causis to the Plotiniana Arabica see Taylor, The Liber de causis (Kalâm fî mahd al-khair), 12 ff. and Richard C. Taylor, "The Kalâm fî mah d alkhair (Liber de causis) in the Islamic Philosophical Milieu," in Pseudo-Aristotle in the Middle Ages: The Theology and Other Texts, ed. Jill Kraye, W. F. Ryan, and C. B. Schmitt (London, 1986), 37-52; see 39 and 45-46. See also D'Ancona Costa, Recherches sur le Liber de causis (Paris, 1995), and "Per un profilo filosofico dell'autore della 'Teologia di Aristotele,'” Medioevo, 17 (1991), 83-134.
} 
known as Plotiniana Arabica, namely, the Theology of Aristotle, the Sayings of the Greek Sage, and the Treatise on Divine Knowledge, were not available to Aquinas in Latin translation. Nevertheless, these played a profound part in his thinking even though the route by which they reached him was far from direct.

The Plotiniana Arabica texts consist of translations and paraphrases of sections of Enneads IV, V, and VI interlaced with additional comments and explanations. ${ }^{35}$ The Pseudo-Aristotelian Theology of Aristotle, the longest of the three texts, consists of ten books which draw on all three Enneads. The Sayings of the Greek Sage, known for the most part from a unique manuscript at Oxford, ${ }^{36}$ is a collection of dicta corresponding again to selected passages of Enneads IV, V, and VI. The third of the texts is the pseudo-Farabian Treatise on Divine Knowledge, based on selections from the fifth Ennead of Plotinus. ${ }^{37}$ Evidence indicates that the materials making up the Plotiniana Arabica came through Syrian Christian hands into Arabic in some form, ${ }^{38}$ but it is nearly certain that the form that these materials now have is not that in which they came into Arabic. ${ }^{39}$

${ }^{35}$ See Maroun Aouad, "La Théologie d'Aristote et autres textes du Plotinus Arabus," in Dictionnaire des philosophes antiques, ed. Richard Goulet (Paris, 1989), 541-90; F. W. Zimmermann, "The Origins of the So-called Theology of Aristotle," in Pseudo-Aristotle in the Middle Ages, 110-240; and Paul B. Fenton, "The Arabic and Hebrew Versions of the Theology of Aristotle," ibid., 241-64; also Plotini Opera II, introduction, XXVII-XXXI; and Abdurrahman Badawi, Aflûț̂n cinda-l-carab (Kuwait, 1977), (1)-(66); Cristina D’Ancona Costa, "La Doctrine Néoplatonicienne de l'être entre l' antique tardive et le moyen âge. Le Liber de causis par rapport à ses sources," in Recherches, 121-53, and other essays in this volume, "Per un Profilo Filosofico..."; also Rémi Brague, "La philosophie dans la Théologie d'Aristote. Pour an inventaire," Documenti e studi sulla traduzione filosofica medievale, 8 (1997), 365-87.

${ }^{36}$ See Plotini Opera II, XXXII-XXXIV.

${ }^{37}$ See Plotini Opera II, XXXI-XXXII.

${ }^{38}$ See Lewis in Plotini Opera II, XXXVI-XXXVI. Also see Paul Kraus, "Plotin chez les Arabes," Bulletin de l'Institute d'Egypte, 23 (1940-41), 263-95, and Pierre Thillet, "Indices Porphyriens dans la Théologie d'Aristote," Le Néoplatonisme (Paris, 1971), 293-302; S. Pines, "Les textes arabes dits Plotiniens et le courant 'Porphyrien' dans le néoplatonisme grec," ibid., 303-13, and 315-17.

${ }^{39}$ Ed. and tr. Geoffrey Lewis in Plotini Opera II. Lewis translates the Treatise on Divine Knowledge and the Theology of Aristotle from his own unpublished edition; a new edition and translation is in A Re-examination of the so-called "Theology of Aristotle" (D. Phil., Oxford University, 1950). The translation of the Treatise on Divine Knowledge in Plotini Opera is based on Lewis's examination of the Istanbul and Cairo manuscripts. The edition of Badawi (see note 35) is based only on the Cairo manuscript. An edition and partial French translation of the Treatise on Divine Knowledge by Paul Kraus was published by G. C. Anawati, O.P., in his "Le Néoplatonisme dans la pensée musulmane: état actuel des recherches," Acta Accademia Nazionale dei Lincei, 198 (1974), 339-405; see 365-405. This Arabic edition by Kraus will be used in this article. For most of the Sayings of the Greek Sage Lewis uses the translation of Franz Rosenthal, "Aš-Šaỵ̣ al-Yûnânî and the Arabic Plotinus Source," Orientalia, 21 (1952), 461-92; 22 (1953), 370-400; 24 (1954), 42-66. These texts are available in an edition published by Abdurrahman Badawi; the Arabic texts of the Sayings of the Greek Sage are also 
On the nature of the First, that is, the One or Good which is outside being, Plotinus clearly differs from Aquinas; for while Plotinus refuses all predicates to the One, even in the last analysis the names One and Good, Aquinas affirms that God is being as ipsum esse per se subsistens, as we have seen. Yet in the Plotiniana Arabica it is unambiguously and repeatedly affirmed that the Pure True One is that which originated or created being, and also that the first originated or created being is $a l-^{c} a q l$ (intellect) which is the source of form for all other lower beings. In this, the Arabic texts are in complete agreement with the texts of Plotinus, but in contrast to Plotinus, the Plotiniana Arabica describes the Pure True One, which is also styled the Pure Good, as the "First Being [al-annîyah al-k̂lâ] which is the cause of intellect, and soul and the other things"40 and as "Pure Being" and "Being alone."

As Pines has pointed out, two fundamental theses run throughout all three Plotiniana Arabica texts. ${ }^{41}$ First, the First Cause, the Creator and the First Agent, is described as pure being; and second, this First Cause is the cause of being and form for some things; that is, it is a complete and perfect cause, while intellect is cause of form only, not being. In the Theology of Aristotle the First is the First Being and the Creator, the cause of all beings, the First True Being, "The Creator Who is the Pure Good." ${ }^{2}$ In the Treatise on Divine Knowledge the First Cause is called "only being" (huwîyah faqat), equivalent to esse tantum in Latin; the intellect which it creates is true being, wa-huwa al-annîyah al-haqq. ${ }^{43}$ The First is said to be "the beginning of being, and ... higher and nobler than substance, because he is the originator of substance"; and the First is "only good. The first good ... the simple which provides all things with good." 4

In the Sayings of the Greek Sage we have the following text which is of special interest here:

He said: The intellect became all things, because its Creator is not like any thing. The First Creator does not resemble any thing, be-

available in an edition published by Franz Rosenthal. Badawi, Aflûțin, 1-164. This work also contains an edition of the Treatise on Divine Knowledge, 165-83, and an edition of the Sayings of the Greek Sage, 184-94. Regarding this edition, see the critical review by Lewis in Oriens, 10 (1957), 395-99. F. Dieterici first edited the Theology in Die sogenannte Theologie des Aristoteles aus arabischen Handschriften zum ersten Mal herausbegeben (Leipzig, 1882) and later translated it into German in Die sogenannte Theologie des Aristoteles aus dem Arabischen übersetzt (Leipzig, 1883).

${ }^{40}$ Badawi, Aflûtîn, 132; cf. Lewis, 289, n.85.

41 "Les textes arabes...," 306-07.

${ }^{42}$ Badawi, Aflûtı̂n, 26-27; Lewis, 231.

${ }^{43}$ Badawi, Aflûtı̂n, 174, 11.9-10 and 172, 11.1-3; Lewis, 321, n.100, 309, n.64.

${ }^{44}$ Lewis translation, 357, n.212 and n.224; Badawi, Aflûtîn, 182.6-7, p. 183.2-3. 
cause all things are from It and because It has no shape and no form belonging to him [lâ hilyah la-hâ wa-lâ șûrah la-hâ]. For the Creator is one alone, that is, It is only being [annîyah faqat] without any attribute attached to it, because all attributes are unfolded from it. In this way all things came to be in it but it is not in any thing except in the mode of cause.

The things are in the intellect and it is in the things. The things came to be in the intellect only because their forms are in it and from it they have unfolded in the things because it is the cause of the things below it. However, although the intellect is a cause of the things below it, it is not a complete cause of the thing because it is only the cause of the thing's form, not the cause of being [huwîyah]. The First Agent is a complete cause, for it is the cause of the being [huwîyah] and form of the thing [the intellect] without intermediary and the cause of the being of soul and the forms of things through the mediation of intellect. Soul and all things are formed in intellect without having been formed in the First Cause, rather they only emanate from It.

All intelligible things are defined [mahdûd]. And the definition of a thing is its shape and its form. For when the First cause created the being [huwiyah] of the things, It did not bring them about as a substrate without definition, but rather It defines them and contains them; and It defines them through their forms. So the definition of the thing produced [ash-shai' al-maf-c$\hat{u} l]$ is its form and its fixity [sukûnu-hu], and fixity is shape and definition for intelligence. And the subsistence and persistence of the intelligence and all other intelligible things is through shape and fixity. ${ }^{45}$

In the light of this passage and others noted earlier, it seems clear that we have here a doctrine that the cause of being is itself pure being, much like the teaching of Aquinas. However, it has been pointed out by Hadot that this is not the first appearance in the history of philosophical thought for such a notion.

A similar notion is found in a Turin palimpsest containing a commentary on parts of the Parmenides of Plato, a commentary which Pierre Hadot argued to be the work of Porphyry or someone of his school $^{46}$ and which H. D.

${ }^{45}$ Badawi, Aflûtîn, 185.4-19. My translation is a modified version of that printed by Lewis in Plotini Opera II, 281, nn. 10-16, corresponding to Enneads V, 1, 7. Note that I render huwîyah as "being," not "identity" as it is found in the Plotini Opera.

${ }^{46}$ See Pierre Hadot, "Dieu comme acte d'être dans le néoplatonisme. A propos des théories d'E. Gilson sur la métaphysique de l'Exode" in Dieu et l'Etre (Paris, 1978), 57-63 and Porphyre et Victorinus (Paris, 1968), and the articles by Hadot cited there; also Cornelia de Vogel, " "Ego sum qui sum' et sa signification pour une philosophie chretienne," Revue des sciences religieuses, 35 (1961), 357-55. 
Saffrey has established as in fact by Porphyry. ${ }^{47}$ There it is maintained, in connection with the Second Hypothesis of the Parmenides, which concerns the One-which-is, that where being is found to be many, there it must be participated. Furthermore, it is said that where ovं ía and ó $\nu$ are participated, there must be posited over them something which is neither $o^{\prime} \nu$ nor ov́ía nor act but rather something which acts and is itself pure acting or

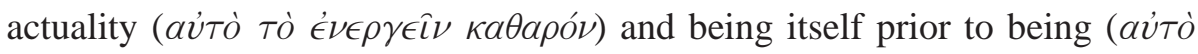

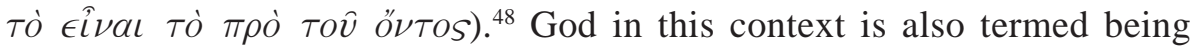

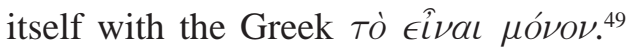

The possible importance of this for the thought of Aquinas has been pointed out by Hadot. ${ }^{50}$ Hadot has also pointed out that similar notions can be found in the De Hebdomadibus of Boethius, a text on which Aquinas commented. ${ }^{51}$

On the Arabic side, both Thillet and Pines have called attention to the similarity of the thought in the Plotiniana Arabica with that of Porphyry as interpreted by Hadot. ${ }^{52}$ Other evidence would also seem to support the arguments on internal evidence given by Thillet and Pines. For the Theology of Aristotle refers to Porphyry in its opening lines:

The First chapter of the book of Aristotle the Philosopher, called in Greek Theologia, being the discourse on the Divine Sovereignty; the interpretation of Porphyry of Tyre, translated into Arabic by ${ }^{\mathrm{c}} \mathrm{Abd}$ alMasih ibn Na'ima of Emessa and corrected for Ahmad ibn al$\mathrm{Mu}^{\mathrm{c}}$ tasim. ${ }^{53}$

It has also been argued that the epithet "Greek Sage," ash-shaikh alyûnânî may well fit Porphyry better than Plotinus. ${ }^{54}$ What is more, we

${ }^{47}$ H.-D. Saffrey, "Connaissance et inconnaissance de Dieu: Porphyre et la Théosophie de Tübingen," in Gonimos. Neoplatonic and Byzantine Studies Presented to L. G. Westerink, ed. J. Duffy and J. Peradotto (Buffalo, 1988), 1-20.

${ }^{48}$ Hadot, Porphyre et Victorinus II, 102-6.

${ }^{49}$ Ibid., 74, IV.8.

${ }^{50}$ Hadot, "L'être et l'étant dans le néoplatonisme," in Etudes Néoplatoniciennes (Neuchatel, 1973), 27-41, repr. from Revue de Théologie et de Philosophie, ser. 3, 23 (1993), 101-15.

${ }^{51}$ Hadot, "Dieu comme acte...," 53. See note 108 below.

${ }^{52}$ See the articles cited in note 38 .

${ }^{53}$ Lewis translation, 486. Badawi, Aflutin, 3. Might Porphyry's understanding of the harmony of Aristotle and Plotinus, particularly in reference to their metaphysical doctrines, have played a role here? See Pierre Hadot, "L'harmonie des philosophies de Plotin et d'Aristote selon Porphyre dans le commentaire de Dexippe sur les Categories," in Plotino e il Neo-platonismo in Oriente e in Occidente, Problemi attuali di scienza e di cultura 198 (Rome, 1974), 31-47, translated as "The harmony of Plotinus and Aristotle according to Porphyry," in Aristotle Transformed: The Ancient Commentators and Their Influence, ed. Richard Sorabji (Ithaca, 1990), 125-40.

${ }^{54}$ Rosenthal, "Aš-Šayḥ," 65, notes that Kutsch has called his attention to the fact that Damascius referred to Porphyry as $\dot{o} \pi \rho \epsilon \sigma \beta \tilde{\tau} \tau \eta S$ and that Porphyry was known as Tyrius senex. 
know that Porphyry was held in highest esteem by many in the Syriac Christian tradition from which most of the early translators came. This is something for which we find evidence in a poetic letter of David bar Paulos (born in the mid-eighth century near Mosul), which states, "Above all the Greeks is the wise Porphyry held in honor, the master of all sciences, after the likeness of the godhead." 55

If the account of the Arabic texts were as straightforward as this, one might then argue that the source of this philosophical notion of the First Cause as pure being both in the West through Boethius and in the East through the Plotiniana Arabica texts may well be Porphyry. However, there are other interpretations. Fritz Zimmermann reasons rather persuasively for another view, contending that Porphyry is mentioned here only because of his well-known role as editor of the Enneads of Plotinus. The name of Plotinus may well have dropped out of the tradition of the text due to scribal error or physical damage to the manuscript. ${ }^{56}$ Still, this does not exclude the influence of the sort of thinking found in the Commentary on the Parmenides by Porphyry from being at work in the Plotiniana Arabica, for late Greek philosophy (and also its understanding in the Syrian Christian tradition) was the source of this stage of Arabic philosophy. ${ }^{57}$ Analyzing details of philosophical arguments of the texts, Cristina D'Ancona Costa has reasoned that the thought of Pseudo-Dionysius may well be at work behind this and other doctrines in the Plotiniana Arabica. ${ }^{58}$ But problems in tracing precise historical sources need not affect appreciation of the philosophical conceptualizing found in the Plotiniana Arabica. How, then, might these philosophical notions of the being of the First Cause and its difference from its creatures or products found in the Plotiniana Arabica have been passed on to Aquinas?

In general the Plotiniana Arabica texts can be characterized as texts foundational for a large part of Islamic philosophy, as well as important for mystical and religious thought in Islam. They function as a kind of doxastic source of a philosophical character of considerable authority for nearly all Islamic philosophical thinkers. ${ }^{59}$ Of the major philosophical thinkers, we

55 "From Antagonism to Assimilation: Syriac Attitudes to Greek Learning," tr. Sebastian Brock in East of Byzantium: Syria and Armenia in the Formative Period, ed. Nina G. Garsoian et al. (Washington, D.C., 1982), 25.

${ }^{56}$ Zimmermann, 120.

${ }^{57}$ See Zimmermann, 122.

${ }^{58}$ She argues for this and against my suggestion of influence of Porphyry at 148-53 of "La Doctrine Néoplatonicienne de l'être," in Recherches, 121-53; and 114-19 of "Cause Prime Non Est Yliathim, Liber de causis. Prop. 8[9]: Les Sources et la Doctrine," ibid., 97-119. I will treat of this topic in detail elsewhere.

${ }^{59}$ Zimmermann (131) argues that "There clearly was a compilation of Greek metaphysics, most probably sponsored by Kindi, which one might loosely describe as Kindi’s metaphysics file. 
can say with certainty that al-Kindi was familiar with some, perhaps even all, of these materials as was al-Farabi who drew on the Theology of Aristotle explicitly in his book on the Harmony of the Opinions of the Two Sages. ${ }^{60}$ Also, al-Farabi's fundamental theory of emanation of all beings from the First Being is clearly dependent on the inspiration of the Plotiniana Arabica texts. The chief inspiration for the notion of the First Cause as pure being and of the theory of emanation in the thought of Avicenna is certainly the work of al-Farabi. ${ }^{61}$ Moreover, we know that Avicenna read the Theology of Aristotle itself, for he has left glosses on the Theology.$^{62}$ In view of this it is not difficult to see that the doctrine of the First as the Necessary Being in the thought of Avicenna had as an important source the Theology of Aristotle. Moreover, as Pines remarks, the consideration of the Plotiniana Arabica texts may well provide some fruitful insights into Avicenna's view of the nature and ontological status of essences. ${ }^{63}$

Thus, in the thought of Avicenna as expressed in his works translated into Latin, the notion of the First as Pure Being, as the Pure Good, as the ultimate efficient cause for all beings through a process of necessary emanation, has roots in the Plotiniana Arabica. To the extent that Aquinas was influenced by the works of Avicenna on these matters, it is the Plotiniana Arabica texts and perhaps Porphyry or Porphyrian ideas which are ultimately responsible. But there is another Arabic source which influenced the thought of Aquinas on this, that is, the Liber de causis.

That file united Ustath's version of the Metaphysics with contributions from post-Aristotelian theology by other translators and adaptors" including materials from Proclus, Alexander, and other Greek sources.

${ }^{60}$ Al-Jam 'baina ra'yai hakîmain, ed. Albert Nadir (Beirut, 1960), 101.

${ }^{61}$ See William Lane Craig, The Cosmological Argument from Plato to Leibnitz (London, 1980), 76-98.

${ }^{62}$ These are edited by ${ }^{\mathrm{c}}$ Abdurrahman Badawi in Arisț $\hat{~}^{c}$ inda al- ${ }^{c}$ arab (Cairo, 1947), 35-74. The text is translated by Georges Vajda in "Les notes d'Avicenne sur la 'Théologie d'Aristote,' " Revue Thomiste, 51 (1951), 346-406. Regarding al-Farabi and Avicenna, see the comments of Zimmermann (177-84) on their knowledge and use of the Theology texts.

${ }^{63}$ Pines, "Les textes arabes...," 313. It seems more likely that Avicenna was inspired by early Islamic theology on this matter, as Averroes charged in his Long Commentary on the Metaphysics of Aristotle. "Avicenna, however, erred greatly in regard to this because he thought that one and being signify dispositions (sifât, dispositiones) added to the essence of the thing. And the marvel is how that man made such an error. That man listened to the theologians when he mixed his own divine science with their accounts." Averroes. Tafsir ma bac d al-Tabicah, ed. M. Bouyges (Beirut, 1948), 313; Latin (Venice, 1574), folios 67B (corresponding to Aristotle, Metaphysics III 3, 1003b23-1004a37), my translation. 
The Liber de causis was translated by Gerard of Cremona from Arabic to Latin sometime in the middle to late twelfth century. ${ }^{64}$ It is a Neoplatonic text consisting of 31 propositions on metaphysical principles and the nature of the First Cause, the separate substances or intelligences, and the higher souls. Probably at first with the title Expositio bonitatis purae reflecting the Arabic Idah fî-l-khair al-mahd, this pseudo-Aristotelian collection of propositions and quasi-proofs came to be known in the Latin world as the Liber de causis. Throughout the lifetime of Aquinas this work was regarded as fit to be used as the companion and completion of Aristotle's Metaphysics. ${ }^{65}$ Aquinas himself made great use of the Liber de causis with citations of the text appearing in many of his major works. It was an authoritative source for him in his Commentary on the Sentences, in his De Ente et essentia, and even in 1271-72, when, in the prooemium of his Super librum de causis expositio, he demonstrated that the Liber de causis in fact consists of excerpts from the Elements of Theology of Proclus. ${ }^{66}$ This has been confirmed in modern times by the work of Bardenhewer and Badawi, who prepared editions of the Arabic text of the Liber de causis. ${ }^{67}$ It has also been confirmed in some detail by Pera who prepared an edition of Aquinas's Commentary. ${ }^{68}$

In 1982 a critical edition of the Arabic text of the Liber de causis was prepared, ${ }^{69}$ providing the opportunity for a thoroughgoing study of the

${ }^{64}$ On Gerard of Cremona see The Dictionary of Scientific Biography, XV, 173-92. A. Pattin, the editor of the text of the Latin De causis, believes the translation of Gerard was corrected by Gundissalinus. See Pattin, "Le Liber de causis," 98-101. The evidence for this is not compelling; see Taylor, "Remarks on the Latin Text."

${ }^{65}$ See Albertus Magnus, Liber de causis et processu universitatis, ed. W. Fauser, in Opera Omnia 17.2 (Münster, 1992), 2.5.24, p.191.17-23 (Borgnet, X, 619b).

${ }^{66}$ See Sancti Thomae de Aquino super librum de causis exposition, ed. H. D. Saffrey (Fribourg, 1954), prooemium, 3. The first translation of this work into a modern language is the Italian translation by Cristina D'Ancona Costa, Tommaso D'Aquino. Commento al "Libro delle Cause" (Milan, 1986); and see the English translation, St. Thomas Aquinas: Commentary on the Book of Causes, tr. Vincent A. Guagliardo, O.P., Charles R. Hess, O.P., and Richard C. Taylor (Washington, D.C., 1996). This discovery, made possible by the 1268 translation of Proclus's Elements of Theology by William of Moerbeke, was likely first made by Moerbeke although Aquinas was the first to remark on it in writing. See Elementatio theologica / Proclus, translata a Guillelmo de Morbecca, ed. Helmut Boese (Leuven, 1987).

${ }^{67}$ See note 5.

${ }^{68}$ S. Thomae Aquinatis in Librum de causis expositio, ed. Ceslai Pera (Rome, 1955), XLVIILII. The critical edition of the Super librum de causis expositio of Aquinas prepared by H. D. Saffrey confirms this through its apparatus fontium.

${ }^{69}$ Leiden, Bibliotheek der Rijksuniversiteit, MS. (Oriental) Golius 209, was the base manuscript for the editions of Bardenhewer and Badawi cited in note 5. On the other manuscripts, see Richard C. Taylor, "Neoplatonic Texts in Turkey: Two Manuscripts Containing IbnṬufayl's Hayy Ibn Yaqzận, Ibn al-Sîd's Kitâb al-Hadâ'iq, Ibn Bâjjah's Ittiṣâl al-cAql bi-l-Insân, the Liber de causis and an Anonymous Neoplatonic Treatise on Motion" Mélanges de l'Institut Dominicain de'Etudes Orientales du Caire, 15 (1982), 251-64; “ “Abd al-Laṭ̂f al-Baghdâdî’s Epitome of the Kalâm fì mahd al-khair (Liber de causis)" in Islamic Theology and Philosophy: Studies in Honor 
Arabic Liber de causis in relation to Proclus's work. ${ }^{70}$ This also showed that the text of Proclus is sometimes modified, if not manipulated, to give the reader notions quite different from those found in the text of Proclus. ${ }^{71}$ More important than that, the isolation of the texts which are not dependent on the Elements of Theology has made possible more than a little insight into the thought of the text's anonymous author and his use of other sources.

What was clear from this study was that, after the Elements of Theology, the major source for what is in the Liber de causis is the Plotiniana Arabica texts or the materials from which the Plotiniana Arabica derive. The isolation of texts not dependent on the Elements of Theology not only allowed for the conclusion that the other major influence on the author of the Liber de causis was this type of modified Plotinian thought, but also

of George F. Hourani, ed. M. E. Marmura (Albany, N.Y., 1984), 236-48, 318-23. My suggestions for revision of Latin edition by Pattin were accepted and published by Winfred Fauser in Alberti Magni ... De causis et processu universitatis a prima causa, ed. Winfridus Fauser, SJ (Cologne, 1993). See Prolegomena, VIb and VIIa. A Latin text also based on Pattin's work and my suggested revisions was published with a French translation of the Latin as La Demeure de l'être: autour d'un anonyme: étude et traduction du Liber de causis, tr. Pierre Magnard et al. (Paris, 1990). The Leiden Arabic manuscript attributes the De causis to Aristotle as does the Latin tradition, while the Ankara manuscript and its Istanbul copy attribute it to Proclus. See Taylor, The Liber de causis (Kalâm fì mahd al-khair), 136; 282; and 54 ff; and Taylor, "The Kalâm fî mahd al-khair (Liber de causis) in the Islamic Philosophical Milieu," 38.

${ }^{70}$ The Arabic text of the De causis, the Kalâm fì mahd al-khair or Discourse on the Pure Good appears to be a product of ninth-century Baghdad; see Taylor, The Liber de causis (Kalâm fì mahd al-khair), 67-70 and "The Kalâm fì mahd al-khair (Liber de causis) in the Islamic Philosophical Milieu," in Pseudo-Aristotle in the Middle Ages, 37-52; see 37-41. This agrees with the conclusions of G. Endress who edited other extant Arabic texts of Proclus's Elements of Theology in his Proclus Arabus. Zwanzig Abschnitte aus der Institutio Theologica in arabischer Ubersetzung (Wiesbaden, 1973). Everett Rowson's discovery of a work by the tenth-century philosopher Abu Ḥasan Muhamammad Ibn Yûșuf al-cÂmirî dependent on the Arabic De causis supports this view. See Everett K. Rowson, "An Unpublished Work by al- ${ }^{c}$ Âmirî and the Date of the Arabic De causis," Journal of the American Oriental Society, 104 (1984), 193-99. The text of al-cÂmirî with translation and study is published in Everett K. Rowson, A Muslim Philosopher on the Soul and its Fate: Al-cÂmirî's Kitâb al-Amad calà al-abad (New Haven, 1988). I have not seen the 1989 dissertation by C. D'Ancona Costa, Causa, potenza, essere: Plotino, Proclo e il De Causis (Rome 1989), to which she refers in note 17, p. 26 of "Sources et structure du Liber de Causis," in Recherches, 23-52. For a collation table of the Arabic De causis or Kalâm fì mahd al-khair and the Elements of Theology of Proclus, see appendix 3, 50, of Taylor, "The Kalâm fî maḥ al-khair (Liber de causis) in the Islamic Philosophical Milieu." That table should be corrected to indicate that Proposition 21 of the Liber de causis is dependent on Proclus's Proposition 131, as found in the collation table given by D'Ancona Costa on p. 191 of her article, "Al-Kindi et l'auteur du Liber de causis," in Recherches sur le Liber de causis (Paris, 1995), 155-91. Her table and mine are not in full agreement, but that issue will be addressed elsewhere.

${ }^{71}$ E. R. Dodds remarks, "The Liber de Causis is not a translation, a paraphrase, or even a systematic abridgement of Proclus's work, and much even of substance has been modified to suit the requirements of a different theology; hence it has little or no value as a subsidium to the Greek text." Proclus: The Elements of Theology (Oxford, 1963²), xliii; and see xxix-xxx. 
made it possible to see clearly that the modifications of the text of Proclus have been made in accordance with this. This has been confirmed and elaborated upon in considerable detail by D'Ancona Costa in a number of valuable articles relating to this topic. ${ }^{72}$

The following is a translation of the eighth proposition of the Arabic Liber de causis, for which there is no corresponding text in the Elements of Theology of Proclus. The text is clearly dependent on modified Plotinian thought, something easily apparent in the light of the text I quoted earlier from the Sayings of the Greek Sage. ${ }^{73}$

The persistence and subsistence of every intellect is through the Pure Good which is the First Cause.

The power of the intellect has stronger unity than the secondary things which are after it, because they do not attain to its knowledge. This has come to be so only because it is cause of what is below it. The proof of that is what we state: the intellect exercises providence over all the things below it through the divine power which is present in it. And by [that power] it keeps hold on the things because through [that power] it is the cause of the things and it keeps hold on and contains all the things below it. For everything which is first for the things and a cause of them keeps hold on those things and exercises providence over them and none of them eludes it owing to its exalted power.

The intellect, then, is the ruler of all the things below it, keeping hold on them and exercising providence over them, just as nature exercises providence over the things which are below it through the power of the intellect. And likewise the intellect exercises providence over nature through Divine Power. The intellect came to keep hold on the things after it and to exercise providence over them and to exalt its power over them only because they are not a substantial power for it, but rather it is the power of substantial powers because it is cause of them.

The intellect contains comings-into-being and nature and what is above nature, namely soul, for it is above nature. For nature contains coming-into-being and soul contains nature and intellect contains soul. The intellect, therefore, contains all things. And the intellect has come to be so only owing to the First Cause which is exalted over all things because It is the cause of intellect, soul, nature and all other things.

\footnotetext{
${ }^{72}$ See her Recherches sur le Liber de causis.

${ }^{73}$ See above pp. 9-10.
} 
The First Cause [, however,] is not intellect nor soul nor nature, but rather It is above intellect, soul and nature because It is creator of all things. However, It is creator of intellect without mediation and creator of soul, nature and all other things through the mediation of intellect. [Moreover,] Divine Knowledge is not like intellectual knowledge nor like the knowledge of soul, but rather it is above the knowledge of intellect and the knowledge of soul because it is creator of all types of knowledge. And Divine Power is above every intellectual, psychic and natural power because It is cause of every power.

The intellect possesses shape $[\text { hilya }]^{74}$ because it is being [annîyah] and form [ș̂rah], and likewise soul possesses shape and nature possesses shape. But for the First Cause there is no shape because It is only being [annîyah faqat]. Thus, if someone says: it is necessary that It have shape, we say: Its shape is infinite and Its Essential Nature [shakhs] ${ }^{75}$ is the Pure Good which pours forth all goods upon the intellect and upon all other things through the mediation of the intellect. ${ }^{76}$

The inspiration for this text seems to come from selections from Enneads $\mathrm{V}$ and VI in which the One, Mind, Soul, and Nature are discussed and appear to be quite in line with those noted earlier. ${ }^{77}$ The First Cause is the Creator of intelligence or $\nu$ ovs and through it, creates all other things. In other chapters of the Liber de causis, in particular chapter 17, in a section which does

${ }^{74}$ This term is a synonym for șûrah, form. See note 45 .

${ }^{75}$ This seems to be the equivalent of the Greek hypostasis.

${ }^{76}$ This translation is based on the Arabic text in Taylor, The Liber de causis (Kalâm fì mahd al-khair), 175-80.

${ }^{77}$ In particular see Enneads 5.5.9; 5.1.7.18-20, 7.25-26; 6.7.17.40-43; and 5.1 title. D'Ancona Costa finds other texts of the Enneads to be the basis for these notions. See " 'Cause Prime Non Est Yliathim'..." in Recherches, $110 \mathrm{ff}$. The De causis text does not contain substantive quotations from the corresponding Plotiniana Arabica though much of the same terminology and phraseology is present. See the lengthy text quoted above on 9-10, and also Treatise on Divine Knowledge, ed. Kraus in Anawati, "L'état," nos. 194-202 (Lewis tr. in Plotini Opera II, 353); Sayings of the Greek Sage, ed. Badawi in Aflûținn, 185.4-19 (Lewis tr. 281, nos. 10-16) and 188.2-189.12 (Lewis tr. 475-76, nos.32-46). Cf. Theology of Aristotle, ed. Badawi in Aflûtı̂n, 134.1-135.5 (Lewis tr. in Plotini Opera II, 291-92, nos.1-12) and Treatise on Divine Knowledge, ed. Kraus, nos. 121-38 (Lewis tr. 323). Proposition 4 of the De causis is dependent on Proclus's Elements of Theology, Proposition 138, but also bears strong resemblance to Enneads IV, 8, 3.6-4.10; IV, 9, 4.2-3, 4.1920, 1.16-18, 2.3-8 and 3.1-4; and VI, 7, 14. These correspond with Sayings of the Greek Sage, in Oxford Bodleian, Marsh MS 539, folios 22v1-25v13 (Lewis tr. 235-37, nos. 47-68. Arabic unpublished); Sayings of the Greek Sage, Marsh 539, folios 38v2-39v8 (Lewis tr. 255, nos. 50-56. Arabic unpublished); and Theology of Aristotle, ed. Badawi in Aflûtı̂n, 97.7-99.8 (Lewis tr., 47173, nos.38-51). D'Ancona Costa finds Proposition 4 to be dependent on Proclus's Propositions " 138,176 , et peut-être inspirations aux propositions 125 et 129." "Al-Kindi et l'auteur du Liber de causis," in Recherches, 191. 
not correspond to a text in Proclus, the author explicitly states that the First Cause gives being (huwîyah) through creation while the intelligence gives to what is below it by way of form, not by way of creation.

[T]he First Being is quiescent and is the cause of causes, and when he gives all things being, he gives it by way of creation. The first life gives life to what is below it not by way of creation but by way of form. And likewise the intelligence gives knowledge and the other things to what is below it only by way of form, not by way of creation, because creation belongs to the First Cause alone. ${ }^{78}$

This, taken together with the description of the First Cause as "only being" and as being without shape, that is, without $\mu о \rho \phi \eta$ or form, clearly shows that the Liber de causis belongs among the Plotiniana Arabica texts. This is also confirmed by more detailed study of similarities of other teachings and as well of stylistic and vocabulary parallels. ${ }^{79}$

As indicated above, Aquinas made extensive use of the Liber de causis throughout his lifetime, and he made considerable use of proposition eight of the Liber de causis, the section not dependent on the Elements of Theology of Proclus but rather on Plotinian thought as found in the Plotiniana Arabica texts. For example, in the De Ente et essentia Aquinas made explicit use of chapter eight of the Liber de causis in explaining that the separate substance of intelligence "is form and being and that it holds its being from the first being, which is being in all its purity; and this is the first cause, God." 80 Aquinas says much the same in his Super librum de causis expositio, where he comments in detail on this chapter. ${ }^{81}$

There can be no question but that the Liber de causis and thereby the Plotiniana Arabica played an important role in the formation of the thought of Aquinas. Considering his use of the Liber de causis and the importance of some Avicennian intuitions for the thought of Aquinas, we are certainly justified in concluding that the thought found in the Plotiniana Arabica, received both directly in the Liber de causis and indirectly in the texts of Avicenna, were of substantial influence in the formation of Aquinas's thought on the notion of God as Ipsum Esse. It may be that the ultimate responsibility for this belongs significantly to Porphyry. In any case it is clear that Plotinus-in modified form-played an important part in the formation of the thought of Aquinas.

\footnotetext{
${ }^{78}$ Taylor, The Liber de causis (Kalâm fì mahd al-khair), 312 (slightly revised translation); Arabic text, Taylor, The Liber de causis (Kalâm fî mahd al-khair), 215-16.

${ }^{79}$ See Taylor, The Liber de causis (Kalâm fî mahd al-khair), 4 ff.

${ }^{80}$ Thomas Aquinas, On Being and Essence, tr. Armand Maurer (Toronto, 1968), 57.

${ }^{81}$ See Sancti Thomae de Aquino super librum..., ed. Saffrey, 62-66.
} 
Can a strong case be made for doctrinal similarity on this philosophical issue independent of the historical transmission of texts? Such is the contention of Lloyd Gerson, who argues that Plotinus's use of "the concept of '́㇒' $\hat{\epsilon}^{\prime} \gamma \epsilon \iota \alpha$, particularly in reference to the One, is most un-Aristotelian." ${ }^{\circ 2}$ Citing Enneads 5.4.2.27-3983 and other texts, ${ }^{84}$ Gerson argues that Plotinus has developed an understanding of évé $\rho \gamma \epsilon \iota \alpha$ which makes it possible to hold that the One, while beyond ov́ría in accord with Plato's fa-

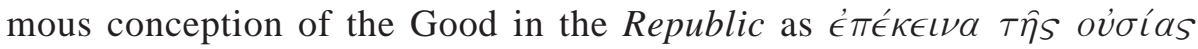
(509B), is nevertheless not without all existence whatsoever. Rather, "for the One to be the $\alpha \rho \chi \eta \dot{~ o f ~ a l l ~ i t ~ c a n n o t ~ b e ~ d e p r i v e d ~ o f ~ e ́ ~} \nu \epsilon \gamma \epsilon \iota \alpha$. To deny energeia of it would be to deny causal efficacy to it. For being an efficient cause means acting as an efficient cause." 85 Gerson's argument, then, is that Plotinus has reached "a primary energeia" 86 which is the One as activity or actuality. His textual foundations for this come from parts of Enneads 6.8:

Nor should we be afraid to assume that the first activity

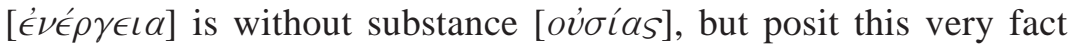

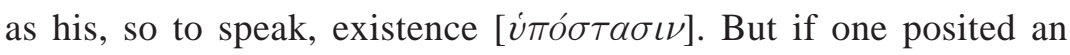
existence without activity, the principle would be defective and the most perfect of all imperfect. And if one adds activity one does not keep the One. If then the activity is more perfect than the substance, and the first is most perfect, the first will be activity. ${ }^{87}$ In his activity, therefore, he is already this first, and it cannot be that he was before he came to be, but already altogether was. Now certainly an activity not enslaved to substance is purely and simply free, and in this way he himself is himself from himself [évé $\rho \gamma \epsilon \iota a$

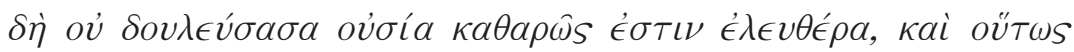

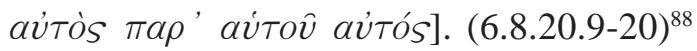

${ }^{82}$ Lloyd P. Gerson, "Plotinus's Metaphysics: Emanation or Creation?" Review of Metaphysics, 46 (1993), 559-74; see 566.

${ }^{83}$ There is an Arabic text corresponding to this which Lewis renders as follows: "The First Agent acts while in repose and in stability. But part of His activity is substance, and part is from substance. The act which is substance is His first act, whereas the act from substance, which comes into being from His act, is the second agent. The second agent necessarily follows the First Agent, but is different from that act, because the <first> act occurred without motion, while the second act occurred with motion" (Lewis, 337.173-175; Arabic in Kraus, 380-81).

${ }^{84}$ Gerson, "Plotinus's Metaphysics," 566 n.23: "Cf. Enneads 2.6.9.14-23, 2.9.8.22-5, 4.5.7.515, 5.1.6.34, 5.3.7.23, 5.9.8.13, 6.2.22.24-9."

${ }^{85}$ Gerson, "Plotinus's Metaphysics," 569.

${ }^{86} \mathrm{Ibid}$. Gerson also discusses this and related issues in his Plotinus (New York, 1994), 15-41.

${ }^{87}$ Gerson, "Plotinus's Metaphysics," 569, quotes from the translation of A. H. Armstrong up to this point.

${ }^{88}$ Plotinus, Enneads, 6. 6-9, tr. A. H. Armstrong, VII (Cambridge, Mass., 1988), 293. 
Gerson's interpretation of the thought of Plotinus on the nature of the One is a matter of some controversy and beyond the scope of this article. However, it is clear that an interpretation of Plotinus along these lines is easily seen to be in accord with the teachings in Porphyry's Commentary on the Parmenides. As indicated above, this doctrine holds for the being of a First Principle which is $\alpha \dot{\tau} \tau \dot{o} \tau o \dot{\epsilon} \nu \epsilon \rho \gamma \epsilon \hat{\imath} \nu \kappa \alpha \theta \alpha \rho o ́ \nu$, pure actuality itself,

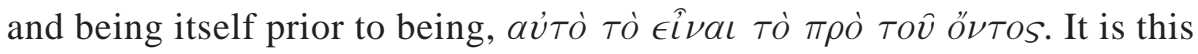
sort of understanding of the One which Gerson asserts Plotinus to argue for in Enneads 6.8. Moreover, in accord with the suggestions of Hadot, ${ }^{89}$ it may well be that Porphyry had in mind this and other passages of 6.8, specifically its discussion of being and actuality, as he wrote his Commentary on the Parmenides.

Of particular interest is language of Plotinus in 6.8.16, where the One is "an actualization of himself," '́ $\nu \in \rho \gamma \epsilon \hat{\imath}$ aútós (6.8.16.18); "His being

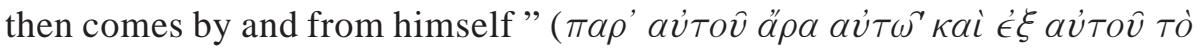

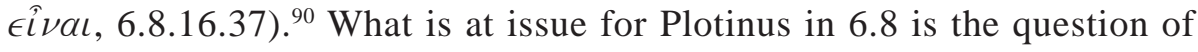
freedom and internal and external necessity in relation to the One, but these issues require metaphysical discussion of the very nature of the One, issues pursued in similar terms by Porphyry in his Commentary. At 6.8.4.2429 Plotinus sets the terms and language of the discussion to follow: "But how is a simple nature and single active actuality [ $\phi \dot{v} \sigma \iota s \delta \dot{\epsilon} a \dot{\pi} \lambda \hat{\eta} \kappa \alpha i$

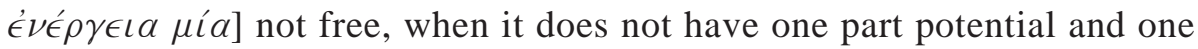
actual? For it could not be said to be active according to nature as if its substance was one thing and its activity another if being and acting there

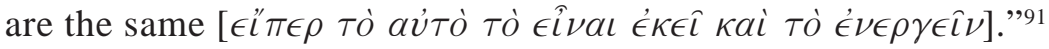

It is precisely this sort of understanding of the First Cause or God which can be found in the Plotiniana Arabica, where it is said,

It is God who originates the beings and forms of things, but He originates some of the forms directly and some of them indirectly. The reason why He originates the beings [annîyât] and forms of things is that $\mathrm{He}$ is the thing truly existing in actuality: indeed $\mathrm{He}$ is the Pure Actuality [huwa ash-shai' al-kâ'in bi-l-ficl haqqan bal huwa al-ficlu al-mahd], and when He acts He does but look at Himself and perform His activity simultaneously. As for the mind, even though it is what is in actuality, since there is something else above it the power of that thing extends to it and consequently it desires

\footnotetext{
${ }^{89}$ Pierre Hadot, "L'être et l'étant dans le néoplatonisme," $32 \mathrm{ff}$.

${ }^{90}$ Armstrong tr., 281-83.

${ }^{91}$ Armstrong, 238-39.
} 
to become like the First Agent, Who is pure actuality [bi-l-fâc $i l^{92}$ al-awwal aladhî huwa ficlun mahdun]. When it wishes to act it does but look at what is above it and perform its activity in the utmost purity. Similarly, even though the soul is what it is in actuality, since the mind is above her something of its power reaches her, and when she acts she does but look at the mind and do what she does. Now the First Agent, who is pure actuality [huwa ficlun maḥun], performs His activity looking at Himself, not at anything outside Himself, for there is nothing else outside Him, that is higher or better than $\mathrm{He} .{ }^{93}$

This text from the Theology of Aristotle is found in the midst of a passage corresponding to parts of Enneads 4.7.83, where one of the topics is energeia, "actuality." Its doctrine, however, seems to follow from Enneads 6.8.20, as cited by Gerson and quoted above. Yet while the Theology of Aristotle draws on Enneads 6.7 and the Sayings of the Greek Sage draws on 6.7 and 6.9, none of the Plotiniana Arabica seems to involve materials which are directly and unequivocally linked to Enneads 6.8. Textually this presents a problem for those seeking to establish strong and direct links between these passages of Arabic and Greek. But is it reasonable to think that those who first crafted what we know as the Plotiniana Arabica possessed a corrupt version of the Enneads, that is, they had Enneads 6.7 and 6.9 but not 6.8 ? That is possible, but might it not be that a paraphrasing Arabic translation of Enneads 6.8 with this doctrine once existed and is no longer extant? Might the author or authors of the Plotiniana Arabica have known Enneads 6.8 well and interpreted it along the lines of Porphyry's thought as we find it in the Commentary on the Parmenides? In that case it would not be necessary to hold that the interpretation of Porphyry in his Commentary on the Parmenides was known to the author or authors of the Plotiniana Arabica but only that they understood Enneads 6.8 in a similar way. ${ }^{94}$ These are matters for further investigation beyond the bounds of the present article.

What is clear from the consideration of these texts is that the understanding of Plotinus on the nature of the One promoted by Gerson in his recent article is

${ }^{92}$ Lewis reads $b i-l-f \hat{a}^{c} i l$ (Agent) with the manuscript Aya Sofia 2457 and not $b i-l-f i^{c} l$ with Oxford Bodleian Ouseley 95, while Badawi follows the conjecture of Dieterici reading $a l^{-}{ }^{c} a q l$ (intellect).

${ }^{93}$ Following the Arabic text of Lewis (see note 39), 73-74, and translated into English in Plotini Opera, ed. Henry and Schwyzer (Paris, 1959), II, 207. I have variously modified Lewis's English rendering of $f i c l$ (from "activity" to "actuality"), annîyât (from "essences" to "beings") and mahd (from "absolute" to "pure"), capitalized references to God, and introduced some other minor changes. The corresponding Arabic in Badawi's edition is p.51.11-52.2; and in Dieterici, 39.9-19.

${ }^{94}$ Hence it is not necessary to exclude the possibility of some influence on the part of the thought of Pseudo-Dionysius. See note 58. 
closely similar to that put forth both by Porphyry in his Commentary on the Parmenides and by the author or authors of the Plotiniana Arabica. These all espouse an understanding of the One as pure actuality or pure activity transcending substance (ovं $\sigma i a)$ and the definiteness and finitude associated with substance in the earlier Greek tradition. In the Arabic tradition and in Porphyry, however, the One also came to be denominated "Pure Being" and "Being alone" and the like.

In light of this, it seems hardly controversial for present day researchers to draw conclusions about the relationship of the thought of Plotinus and Thomas Aquinas quite different from those held by Gilson. Whether or not it is the correct interpretation of Plotinus, it is clear that the Arabic tradition was much influenced by an understanding of the True One or Good in the Plotiniana Arabica quite in accord with the Porphyrian doctrine in the Turin palimpsest, that the First Principle of all is Pure Actuality and that all other things participate in actuality. In the Plotiniana Arabica the notion of the First Principle as Pure Being seems naturally to have led to the doctrine of the Liber de causis on mediate creation, namely, that the First Being (al-huwîyatu al-îlà) alone gives being by creation (Proposition 17 [18]) and that being given by the First Cause is the foundation for any other perfections or characteristics in a thing (Proposition 1). ${ }^{95}$ Aquinas received much metaphysical inspiration from many diverse sources, including Aristotle, Augustine, Boethius, Avicenna, Averroes, Pseudo-Dionysius, Sacred Scripture, William of Auvergne, and Albertus Magnus; but from all these he selected and used what he deemed sound and clearly made his own only so much tradition as he saw fit to pass on as true. In the case of the texts considered in this article, Aquinas made his own the notion of God as ipsum esse and esse tantum and was in agreement with the Plotiniana Arabica that the First Cause is pure actuality. ${ }^{96} \mathrm{He}$ also was in agreement that creation properly so called belongs to God alone.

Let me conclude by summarizing some of the links or connections which have been made in this article. First, textual links between the thought of Plotinus and the Plotiniana Arabica are obvious. Second, textual links between the thought of Aquinas and that of the Liber de causis are equally obvious. Third, terminology and doctrine textually associate the Liber de causis and the Plotiniana Arabica, with the likelihood that the Liber de causis is posterior to the Plotiniana Arabica and that in any case they are

${ }^{95}$ Taylor, The Liber de causis (Kalâm fî maḥ al-khair), 213-16 and 137-44; Otto Bardenhewer, Die pseudo-aristotelische ... Liber de causis, 92 and 58-61; Badawi, Al-Aflâtûnîyah almuhdathah, 19 and 3-4; Pattin, "Le Liber de causis...," 85-86 and 46-50 .

${ }^{96}$ Solus Deus est actus purus. Unde in solo Deo sua substantia est suum esse et suum agere. ST 1.4.1 resp. (Ottawa, 1943), I, 333a 34-36. 
closely connected and appear to stem from a single philosophical approach. Fourth, some similarity of terminology (the use and understanding of the terms $\epsilon^{\prime} \nu \epsilon \rho \epsilon \iota \alpha$ or $\dot{\epsilon}^{\prime} \nu \epsilon \rho \epsilon \epsilon \bar{\imath} \nu$ ) may be said to indicate the likelihood of a connection of the thought of Plotinus on the One in Enneads 6.8 and that of the Porphyry in his Commentary on the Parmenides. Plotiniana Arabica texts corresponding to sections of Plotinus's Enneads 6.7 and 6.9 are extant. If there was an Arabic version of 6.8 (where the doctrine of the One as transcendent actuality is entertained by Plotinus), it may well have contained an account of the One as actuality similar to what we find in Porphyry. It may be, then, that a lost Arabic text of 6.8 - or a knowledge of the doctrine of 6.8 on the part of the translators-is a key source for the doctrine of pure actuality.

What sort of doctrinal or philosophical links can be made? First, the doctrine of the First Principle or First Cause as pure being and as only being as read by Aquinas in the Liber de causis can be traced to the Plotiniana Arabica or its source which transformed Greek Neoplatonic thinking on the One into a metaphysics of being. To this extent, the doctrine can be said to be at the origins of the Islamic philosophical tradition. Secondly, philosophical doctrine seems to link the Porphyrian teaching on the First Principle to Plotinus as a possible understanding based on an interpretation of Enneads 6.8.4-20 along the lines suggested by Gerson. Third, Porphyrian philosophical understanding is doctrinally similar to that of the Plotiniana Arabica in virtue of its teaching on the First Principle both as pure being and as pure actuality or activity. Fourth, it may not be necessary to bring Porphyry into the picture at all insofar as the doctrines in the Plotiniana Arabica on the First Cause as being and actuality can quite plausibly be read as what would be expected from a Plotiniana Arabica version of Enneads 6.8.4-20. Fifth, although the notion of God as pure actuality does not occur explicitly in the Liber de causis, it perhaps can be seen as a natural consequence of other doctrines in the Liber de causis and other philosophical materials available in the Arabic tradition. Finally, Aquinas can be said to have been influenced by these and other Arabic philosophical materials as well as philosophical and theological materials from the Latin tradition, but his critical synthesis of these notions into his own doctrine of Essence and Existence is a new and exciting philosophical development building upon but not identical with what preceded him in the history of philosophy.

Clearly, the Liber de causis has a central place in the Medieval metaphysical corpus for its transmission to the Latin West of philosophical notions about the nature of being and the nature of the First Principle developed out of the Plotinian tradition. To the Latin West this was a significant contribution and the Liber de causis was recognized as important. But the evi- 
dence seems to indicate that the most well-known philosophers of the Arabic tradition paid little attention to this work, ${ }^{97}$ perhaps in part because they had the Theology of Aristotle and the other Plotiniana Arabica at their disposal.

Marquette University.

${ }^{97}$ See Taylor, "The Kalâm fî mahd al-khair (Liber de causis) in the Islamic Philosophical Milieu," 40-43. 